\title{
Genetic variation and population structure of Asarum misandrum (Aristolochiaceae) in Korea
}

\author{
Soonku So and Muyeol Kim* \\ Department of Biological Sciences, Chonbuk National University, Jeonju 561-756 Korea \\ (Received 1 May 2013; Accepted 9 September 2013)
}

\section{각시족도리풀(Asarum misandrum)의 유전적 다양성 및 집단 구조}

\author{
소순구 · 김무열* \\ 전북대학교자연과학대학 생명과학과
}

\begin{abstract}
Genetic variation in Asaum misandrum, a woodland herb in Korea, was investigated based on allozyme analysis with starch gel electrophoresis. All of previously reported populations in Korea were sampled and seven loci from six enzymes were analyzed. Overall genetic variation of $A$. misandrum population showed considerably high levels of genetic variation within the species $\left(\mathrm{A}=2.05, \mathrm{P}=71.4, \mathrm{H}_{\mathrm{E}}=0.294\right)$. A positive $\mathrm{F}_{\mathrm{IS}}$ value of $A$. misandrum indicated overall deficiency of heterozygotes, and a low $\mathrm{F}_{\mathrm{ST}}$ value $(0.112)$ meant very little differentiation among populations. Factors contributing to the high levels of genetic diversity found within populations of $A$. misandrum include population maintenance via wide distribution range from Korea to Japan and primarily outcrossing breeding system. Although it showed moderate genetic diversity level, most habitats of the species were scattered and discontinuous. Besides, low numbers of individuals were found in the most habitats and individuals are collected frequently from the wild due to the unique shape of the flowers as well as the rarity of the species. Thus, there is a need to set up a reasonable conservation strategies including the maintenance mechanism of genetic diversity of $A$. misandrum.
\end{abstract}

Keywords: Asarum misandrum, Genetic variation, Conservation, Korean peninsula, Aristolochiaceae

적 요: 한국과 일본에만 한정 분포하는 각시족도리풀(Asarum misandrum) 4개 집단의 자생지 상태와 합리적인 보전전략의 수립을 위하여 7개의 allozyme marker를 이용하여 유전적 다양성과 구조를 분석하였다. 각시족도리 풀 집단의 대립 유전자의 수 $(\mathrm{A})$ 는 2.05 개, 다형적 유전좌위의 비율 $(\mathrm{P})$ 은 $71.4 \%$, 이형접합체의 평균 기대치 $\left(\mathrm{H}_{\mathrm{E}}\right)$ 는 0.294 를 나타내어 분포 역이 넓고 주로 내륙에 분포하는 특산식물과 유사하거나 다소 높은 수준의 유전적 다양 도를 유지하고 있는데, 그 이유는 자가수분이 가능하지만 타가수정을 주로 하기 때문인 것으로 판단된다. 유전 적 구조분석 결과 집단간 $\mathrm{F}_{\mathrm{IS}}$ 는 양의 값을 나타내었고 집단간 유전적 분화도는 매우 낮은 결과 $(0.112)$ 를 보였다. 각시족도리풀의 자생지가 비록 적정 수준의 유전적 다양도을 보이고 있지만, 한국과 일본의 남쪽지방에만 한정 분포하는 특징, 불연속적이고 분산되어있는 자생지의 상태, 대부분의 자생지에서 적은 개체가 나타나며 특이하 고 희귀한 꽃 때문에 남획될 가능성이 높다는 점 등은 이 식물의 보전을 위한 관심을 필요로 한다. 각시족도리 풀은 최근에 기록되어 현재 희귀식물로 지정된 종은 아니지만 보전적 가치가 높다고 판단되며 이 종의 보전을 위해 종 생물학적 정보를 수집하고 유전적 변이의 유지기작을 포함한 합리적인 보전전략의 수립이 요구된다.

주요어: 각시족도리풀, 유전적 변이, 보전, 쥐방울덩굴과

\footnotetext{
*Author for correspondence: mykim@jbnu.ac.kr
}

http://www.pltaxa.or.kr

Copyright (C) 2013 the Korean Society of Plant Taxonomists 
Genetic diversity, the level of biodiversity, plays a very important role in species' survival and adaptability of a species. Genetic diversity is required for populations to evolve in response to environmental changes (Reed and Frankham, 2003) and thus, the vulnerability of a population to certain types of historical events can also increase with a reduction in genetic diversity. In plants, breeding system can significantly affect genetic diversity and its partitioning within and among populations (Hamrick and Godt, 1996).

The genus Asarum consists of 70-90 species of low-growing perennial herbs in the family Aristolochiaceae, and is widely distributed in temperate and warm temperate zone of Europe, North America and Asia in the Northern Hemisphere (Huber, 1993; Kelly, 1998). Of them, 3 species and 7 forma of the genus Asarum occur in Korea (So and Kim, 2008).

According to the phylogenetic study, Asarum is well supported as monophyletic and is distinguished from the other genera of Aristolochiaceae by 2 foliage leaves, 2-cataphylls, and a fleshy or spongy capsule (Kelly, 1997; Kelly, 1998). Based on a study of morphology on Asarum, several new taxa were recently discovered in Korea and subsequently described (e.g., Yamaki et al., 1996; Yook and Kim, 1996; Oh et al., 1997; So et al., 2010). Also, all members of the taxa are poisonous and have been used traditionally as a herbal medicine for medicinal purpose. For this reason, researches on Asarum were mainly focused on the taxonomic study and medicinal researches. Therefore, there is little information about genetic variation in population, genetic structure and conservation.

Plant-animal interactions often play a strong role in determining plant abundance and persistence of a plant population in the ecosystem (Knight, 2007). Shin (1991) reported significance of the ecological niche of Asarum species. Asarum is known to be a food source specific to the larvae of Luehdorfia puziloi (Lepidoptera: Papilionidae). Also, L. puziloi is a major pollinator of the spring ephemeral herb Erythronium japonicum (Liliaceae) (Ishizaki et al., 2010; Shin, 1991). It is thought that Asarum species plays a very important role in the ecosystem as a keystone species.

Of three Korean Asarum species, A. misandrum is a perennial herb which has been described as a new species by Oh et al. (1997) and this species is distinguished from the other species within the genus by strongly recurved calyx lobes which adhere closely to calyx tube, no trichomes on adaxial leaf surface and petiole, and smaller size of plant.

Through our field research, Asarum misandrum is found mainly in the moist and shaded sites of the woodland in Korea and this species occurs with lower trees, Quercus acutissima, Lindera obtusiloba and Lindera erythrocarpa, and herbaceous plants, Hedera rhombea, Trachelospermum asiaticum, Liriope platyphylla and etc. Current status of $A$. misandrum populations is limited to the south-western coastal area of Korea and low numbers of individuals were found. Also, most habitats are discontinuous and scattered (S. So, pers. obs.). However, no research has examined yet the genetic variation of $A$. misandrum populations in order to construct an effective conservation plan.

The purpose of the present study was to investigate the genetic diversity and differentiation within and among natural populations of A. misandrum in Korea based on the investigation of their allozymes. The main objectives of the study were to (a) access levels of genetic diversity of populations, (b) evaluate the degree of differentiation among populations, and (c) provide baseline information for establishing management practices to preserve this species and habitats.

\section{Materials and Methods}

Asarum misandrum sample groups of 18 individuals on average were collected from four natural populations in Korea (Fig. 1; Table 1). Those four sites were the representative habitats of A. misandrum in Korea and they were living mainly in the shaded sites on the mountain sides. Collections of individuals from each sites were made at least $5 \mathrm{~m}$ apart to
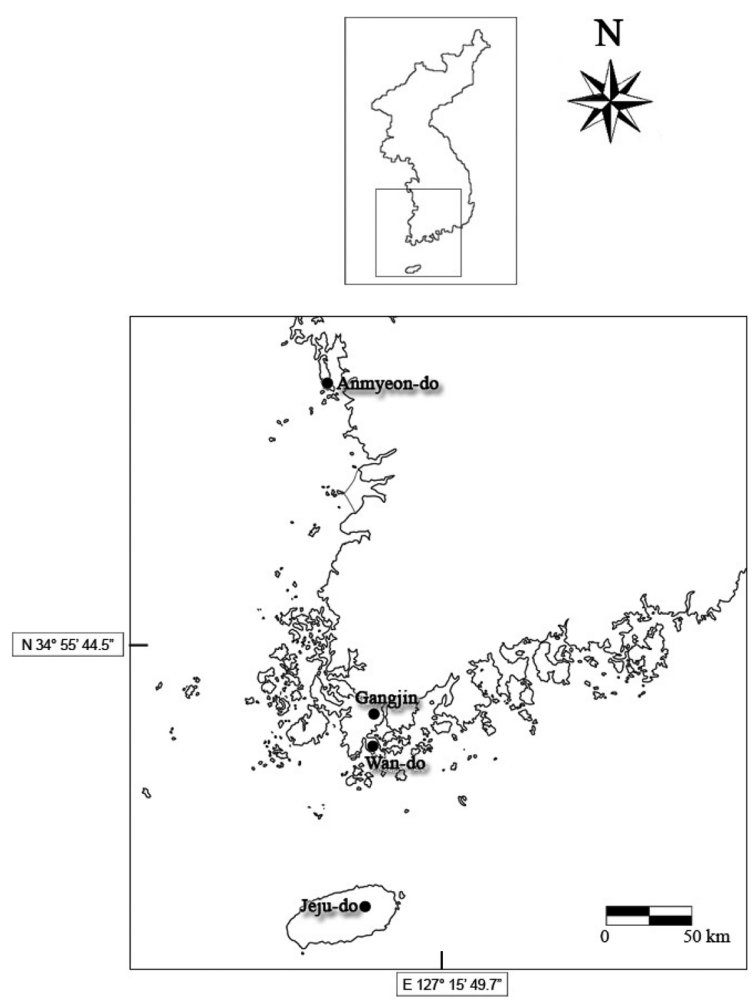

Fig. 1. Distribution of Asarum misandrum in Korea. 
Table 1. Collection sites for four populations of Asarum misandrum for the allozyme analyses.

\begin{tabular}{llc}
\hline \hline Population name & \multicolumn{1}{c}{ Location } & Number of samples \\
\hline 1 Anmyeon-do & $\begin{array}{l}\text { Anmyeon-do, Taean-gun, } \\
\text { Chungnam, Korea }\end{array}$ & 18 \\
\multirow{2}{*}{ 2 Gangjin } & $\begin{array}{l}\text { Gangjin-gun, Jeonnam, } \\
\text { Korea }\end{array}$ & 18 \\
3 Jeju-do & $\begin{array}{l}\text { Jeju-do, Korea } \\
\text { Wan-do, Wando-gun, } \\
\text { 4 Wan-do }\end{array}$ & 18 \\
\hline
\end{tabular}

reduce the likelihood of collecting clones. Young leaves are collected and stored at 4 until the experiment.

For the survey of allozymes within the species using the starch gel electrophoresis, samples were pulverized and ground in porcelain dish using extracting buffer containing $0.1 \mathrm{M}$ tris$\mathrm{HCl}, \mathrm{pH} 7.5,1 \mathrm{mM}$ EDTA (tetrasodium salt), $10 \mathrm{mM} \mathrm{MgCl}$, $10 \mathrm{mM} \mathrm{KCl}, 14 \mathrm{mM}$ 2-mercaptoethanol, and $5-10 \mathrm{mg} / \mathrm{ml}$ solid polyvinylpyrrolidone (Gottlieb, 1981). Four chromatography paper wicks approximately $15 \mathrm{~mm}$ long and 3-4 mm wide were dipped into each sample solution, and were stored under $-60^{\circ} \mathrm{C}$ refrigerator before the actual electrophoresis.

Each wick was then processed through electrophoresis with $13 \%$ starch gel using two buffer systems. An electrode buffer of $0.065 \mathrm{M}$ L-histidine and $0.007 \mathrm{M}$ citric acid, adjusted to $\mathrm{pH}$ 6.5 with $\mathrm{NaOH}$ was diluted by $1: 3$ ratio for System I. Another electrode buffer of 0.18 tris, $0.1 \mathrm{M}$ Boric acid, and $0.004 \mathrm{M}$ EDTA, pH 8.6, also diluted according to $1: 3$ ratio was used for System II. The whole process of electrophoresis was carried out inside a refrigerator under $4^{\circ} \mathrm{C}$. Gel systems were run at $40 \mathrm{~mA}$ for about 5 hours. Enzyme-activity staining and agarose overlays generally followed the protocols of Soltis et al. (1983). Loci and alleles were numbered sequentially and lettered alphabetically beginning with the most anodal form. Total of eleven enzymes were assayed by using System I and II; glyceraldehydes-3phosphate dehydrogenase (GA3PD), 6-phosphogluconate dehydrogenase (6PGD), malate dehydrogenase (MDH), aldolase (ALD) and shikimate dehydrogenase (SKDH) were assayed with System I, while malic enzyme (ME), phosphoglucose isomerase (PGI), phosphoglucomutase (PGM), aspartate aminotransferase (AAT) and alcohol dehydrogenase (ADH), menedione reductase (MNR) were resolved with System II.

The mean number of alleles per locus (A), percentage of polymorphic loci $(\mathrm{P})$, average observed heterozygosity $\left(\mathrm{H}_{\mathrm{O}}\right)$, and mean expected heterozygosity $\left(\mathrm{H}_{\mathrm{E}}\right)$ of the 20 samples from each group were studied by using BIOSYS-1 program (Swofford and Selander, 1981). Also, to study the population differentiation,
Wright's F-statistics were calculated. It includes $\mathrm{F}_{\mathrm{IS}}$, an index of inbreeding, $F_{\mathrm{IT}}$, the overall inbreeding coefficient, and $\mathrm{F}_{\mathrm{ST}}$, a measure of the genetic differentiation among populations (Wright, 1965). UPGMA tree was produced by input of Nei's genetic identity values into the BIOSYS-1 program.

\section{Results}

Of the six enzymes evaluated, one (ADH) could be consistently resolved and scored for two interpretable loci (ADH-1 and ADH-3) while only one isozyme locus of the remaining enzymes could be scored. Out of seven loci, all seven were polymorphic among four populations of Asarum misandrum inhabiting in Korean peninsula; allele a of ME-2 was unique to population 2 (Gangjin); allele b of ADH-1 was unique to population 1 (Anmyeon-do); allele a of SKDH2 was unique to population 3 (Jeju-do) (Table 2).

All populations had $71.4 \%$ of polymorphic loci. The mean number of alleles per locus ranged from 2.0 to 2.1 with the

Table 2. Summary allele-frequency of Asarum misandrum in Korea.

\begin{tabular}{|c|c|c|c|c|}
\hline Locus & Anmyeon-do & Gangjin & Jeju-do & Wan-do \\
\hline \multicolumn{5}{|l|}{ PGM-1 } \\
\hline $\mathrm{a}$ & 0.412 & 0.353 & 0.833 & 0.500 \\
\hline $\mathrm{b}$ & 0.529 & 0.471 & 0.111 & 0.375 \\
\hline $\mathrm{c}$ & 0.059 & 0.176 & 0.056 & 0.125 \\
\hline \multicolumn{5}{|l|}{ ME-2 } \\
\hline $\mathrm{a}$ & 0.000 & 0.176 & 0.000 & 0.000 \\
\hline $\mathrm{b}$ & 1.000 & 0.765 & 1.000 & 0.813 \\
\hline $\mathrm{c}$ & 0.000 & 0.059 & 0.000 & 0.188 \\
\hline \multicolumn{5}{|l|}{ ADH-1 } \\
\hline $\mathrm{a}$ & 0.765 & 1.000 & 1.000 & 1.000 \\
\hline $\mathrm{b}$ & 0.235 & 0.000 & 0.000 & 0.000 \\
\hline \multicolumn{5}{|l|}{ ADH-3 } \\
\hline $\mathrm{a}$ & 0.528 & 0.438 & 0.722 & 0.000 \\
\hline $\mathrm{b}$ & 0.472 & 0.563 & 0.278 & 1.000 \\
\hline \multicolumn{5}{|l|}{ PGI-1 } \\
\hline $\mathrm{a}$ & 0.583 & 0.559 & 0.536 & 0.607 \\
\hline $\mathrm{b}$ & 0.139 & 0.206 & 0.179 & 0.071 \\
\hline $\mathrm{c}$ & 0.278 & 0.235 & 0.286 & 0.321 \\
\hline \multicolumn{5}{|l|}{ 6PGD-2 } \\
\hline $\mathrm{a}$ & 0.111 & 0.059 & 0.111 & 0.176 \\
\hline $\mathrm{b}$ & 0.889 & 0.941 & 0.889 & 0.824 \\
\hline \multicolumn{5}{|l|}{ SKDH2 } \\
\hline $\mathrm{a}$ & 0.000 & 0.000 & 0.059 & 0.000 \\
\hline $\mathrm{b}$ & 1.000 & 1.000 & 0.882 & 0.875 \\
\hline $\mathrm{c}$ & 0.000 & 0.000 & 0.059 & 0.125 \\
\hline
\end{tabular}


lowest being population 1 and 4 (Anmyeon-do and Wan-do) and the highest being population 2 and 3 (Gangjin and Jejudo). The mean heterozygosity expected by Hardy-Weinberg equilibrium ranged from 0.251 to 0.318 and averaged 0.294 . The mean heterozygosity observed ranged from 0.112 to 0.212 and averaged 0.162. All populations showed lower observed heterozygosity than expected by Hardy-Weinberg equilibrium (Table 3). This clearly indicated severe heterozygote deficit.

Observed genotype proportions were compared to those expected by the Hardy-Weinberg equilibrium by calculating the fixation index (F) for each polymorphic locus in each population. The statistical difference of the $\mathrm{F}$ value from 0 was then calculated by using the chi-square test (Table 5 ). Of the 20 valid tests, 6 loci showed accordance to Hardy-Weinberg proportions, while most of the remaining loci were significantly different from the Hardy-Weinberg equilibrium and the value of $\mathrm{F}$ exceeded 0 , indicating heterozygote deficiency.

$\mathrm{F}$ statistics was used to measure the degree of genetic differentiation among four populations of $A$. misandrum. $\mathrm{F}_{\mathrm{IS}}$ value indicates the degree of divergence from Hardy-Weinberg expectations within populations. $\mathrm{F}_{\mathrm{IT}}$ value indicates the degree

Table 3. Mean sample size per locus $(N)$, mean values of alleles per locus (A), percentage of polymorphic loci (P), mean observed heterozygosity $\left(\mathrm{H}_{\mathrm{O}}\right)$, and mean expected heterozygosity $\left(\mathrm{H}_{\mathrm{E}}\right)$ in four populations of Asarum misandrum in Korea.

\begin{tabular}{lccccc}
\hline \hline Population & $\mathrm{N}$ & $\mathrm{A}$ & $\mathrm{P}$ & $\mathrm{H}_{\mathrm{O}}$ & $\mathrm{H}_{\mathrm{E}}$ \\
\hline 1 Anmyeon-do & 16.7 & 2.0 & 71.4 & 0.143 & 0.318 \\
2 Gangjin & 16.1 & 2.1 & 71.4 & 0.180 & 0.323 \\
3 Jeju-do & 17.1 & 2.1 & 71.4 & 0.212 & 0.251 \\
4 Wan-do & 15.0 & 2.0 & 71.4 & 0.112 & 0.285 \\
Mean & 16.2 & 2.1 & 71.4 & 0.162 & 0.294 \\
\hline
\end{tabular}

Table 4. Summary of F-statistics at 7 loci from four populations of Asarum misandrum. $\mathrm{F}_{\mathrm{IS}}$, an index of inbreeding, $\mathrm{F}_{\mathrm{TT}}$, the overall inbreeding coefficient, and $\mathrm{F}_{\mathrm{ST}}$, a measure of the genetic differentiation among populations.

\begin{tabular}{lccc}
\hline \hline \multicolumn{1}{c}{ Locus } & $\mathrm{F}_{\text {IS }}$ & $\mathrm{F}_{\text {IT }}$ & $\mathrm{F}_{\text {ST }}$ \\
\hline PGM-1 & 1.000 & 1.000 & 0.109 \\
ME-2 & 1.000 & 1.000 & 0.119 \\
ADH-1 & 1.000 & 0.438 & 0.187 \\
ADH-3 & 0.212 & -0.496 & 0.287 \\
PGI-1 & -0.507 & 1.000 & 0.007 \\
6PGD-2 & 1.000 & 1.000 & 0.017 \\
SKDH2 & 1.000 & 1.000 & 0.061 \\
Mean & 0.672 & 0.706 & 0.112 \\
\hline
\end{tabular}

of divergence from Hardy-Weinberg expectation among total population. $\mathrm{F}_{\mathrm{ST}}$ indicates allele frequency divergence among populations (Allendorf and Luikart, 2007). Although few loci (PGI-1 and ADH-3) of A. misandrum had negative $\mathrm{F}_{\mathrm{IS}}$ and $\mathrm{F}_{\mathrm{IT}}$ values, the mean $\mathrm{F}_{\mathrm{IS}}$ and $\mathrm{F}_{\mathrm{IT}}$ value of all seven loci of $A$. misandrum studied were 0.672 and 0.706 , respectively, which indicated overall deficiency of heterozygote compared to the Hardy-Weinberg expectation. The mean $\mathrm{F}_{\mathrm{ST}}$ value of seven loci of A. misandrum was 0.112 , which means very little differentiation among populations (Table 4).

The Nei's unbiased genetic identity (Nei, 1978) showed that four populations studied were close to each other in pairwise comparison. The genetic identity values ranged from 0.872 for the comparison between population 3 (Jeju-do) and 4 (Wan-

Table 5. Value of the fixation index $\mathrm{F}$ for polymorphic loci in populations of Asarum misandrum. Consistency with the HardyWeinberg equilibrium, i.e., statistical difference of fixation indices from 0 , was evaluated using chi-square analysis and is indicated via asterisks: ${ }^{*} \mathrm{P}<0.005$

\begin{tabular}{lcccc}
\hline \multicolumn{1}{c}{ Locus } & Anmyeon-do & Gangjin & Jeju-do & Wan-do \\
\hline PGM-1 & $1.000^{*}$ & $1.000^{*}$ & $1.000^{*}$ & $1.000^{*}$ \\
ME-2 & - & $1.000^{*}$ & - & $1.000^{*}$ \\
ADH-1 & $1.000^{*}$ & - & - & - \\
ADH-3 & $0.666^{*}$ & 0.238 & -0.385 & - \\
PGI-1 & -0.479 & -0.496 & -0.549 & -0.502 \\
6PGD-2 & $1.000^{*}$ & $1.000^{*}$ & $1.000^{*}$ & $1.000^{*}$ \\
SKDH2 & - & - & $1.000^{*}$ & $1.000^{*}$ \\
\hline
\end{tabular}

Table 6. Mean values for Nei's (1978) unbiased genetic identity coefficient for pair-wise comparisons of populations of Asarum misandrum in Korea.

\begin{tabular}{lcccc}
\hline \hline & 1 & 2 & 3 & 4 \\
\hline 1 Anmyeon-do & - & & & \\
2 Gangjin & 0.974 & - & & \\
3 Jeju-do & 0.945 & 0.936 & - & \\
4 Wan-do & 0.917 & 0.944 & 0.872 & - \\
\hline
\end{tabular}

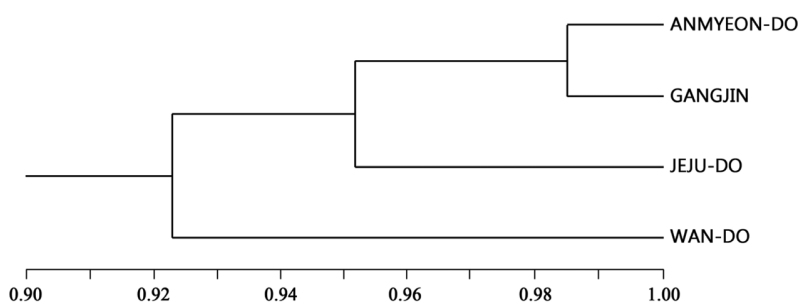

Fig. 2. UPGMA phenogram derived from Nei's genetic identity of four populations of Asarum misandrum in Korea. 
do) to 0.974 for the comparison between population 1 (Anmyeon-do) and 2 (Gangin) (Table 6). Further investigation showed that population 4 (Wan-do), although still genetically close to other population, was the farthest from other populations in terms of Nei's genetic identity values. A UPGMA phenogram based on genetic identity values were constructed to examine genetic relationships among four populations of $A$. misandrum (Fig. 2).

\section{Discussion}

\section{Genetic variation and population structure}

Asarum misandrum maintains considerably higher levels of genetic variation $\left(\mathrm{A}=2.05, \mathrm{P}=71.4, \mathrm{H}_{\mathrm{E}}=0.294\right)$, similar to that of continental endemic species. In case of Korean continental endemic plants, for example, it showed higher level of genetic variation than that of Hosta minor $(\mathrm{A}=1.68, \mathrm{P}=$ $52.59, \mathrm{H}_{\mathrm{E}}=0.230$ ) (Chung, 1994) and lower level than that of Eranthis byunsanensis ( $\mathrm{A}=2.4, \mathrm{P}=90.0, \mathrm{H}_{\mathrm{E}}=0.311$ ) (So et al., 2013) and Hemerocallis hakuunensis $(\mathrm{A}=3.17, \mathrm{P}=$ 75.0, $\mathrm{H}_{\mathrm{E}}=0.253$ ) (Kang and Chung, 1997).

Generally, selfing species tend to have lower genetic diversity and heterozygosity within populations, as well as higher genetic differentiation among populations, than mixed or outcrossing ones (Hamrick and Godt, 1989; Nybom and Bartish, 2000). Although breeding system of A. misandrum has not been studied previously, there has been much speculation about the pollination biology of Asarum species due to unique shape of flowers. According to previous pollination studies of Asarum species, it was proposed that these species are allogamous and pollinated by carrion insects including flies (Peattie, 1940; Lu, 1982). Also, it was observed that in flowering period of $A$. caudatum, the anthers dehisce near the stigmas and self-pollination occurs (Lu, 1982). Thus, A. misandrum is more likely to be a self-compatible but pollinator-dependent outcrosser and these are factors contributing to the high levels of genetic diversity found within populations.

All four populations of $A$. misandrum had a low $\mathrm{F}_{\mathrm{ST}}$ value, which indicates a close similarity between populations. It ranged from 0.007 (PGI-1) to 0.287 (ADH-3) and the mean value was 0.112 . In comparison with the average value of perennial herbs $\left(\mathrm{G}_{\mathrm{ST}}=0.213\right)$ (Hamrick and Godt, 1989), it was lower than that of $A$. misandrum populations and showed that not much divergence among populations and it suggested that this species has not had much time yet to differentiate among populations since arriving at Korean peninsula. According to phylogeny and evolution study of Asarum, interactions including migration, hybridization, and introgression presumed Korean Asarum species had migrated to Japan via a southern route from Korea (Yamaji et al., 2007). Additionally, Asarum species in Korea and Japan mainly had slightly or no polymorphism of the ITS sequences and these results supported the evidence for the origin of A. misandrum.

\section{Conservation implication}

Information on the genetic and demographic structure of populations of the species is essential for establishing comprehensive conservation plans (Wallace, 2002). The measurement and maintenance of genetic variability is one of the most important part of conservation biology and knowledge on its levels and pattern provides essential background information for effective conservation strategies (Avise and Hamrick, 1996; Zhou et al., 2010).

Historical factors might provide one possible explanation for the high genetic variation and low levels of genetic differentiation detected in A. misandrum. Earlier it was known to occur only in the southern parts of Korean peninsula (Oh et al., 1997) but they have been lately found in some isolated localities in Korea such as Anmyeon-do and also in Kyushu, Japan (Yamaji et al., 2007; So and Kim, 2008).

Smaller populations, which can be typical of endangered species, are especially vulnerable to loss of variation through stochastic events (Wallace, 2002). Although it showed high genetic diversity, most habitats in Korea were small, discontinuous and were scattered. Besides, low numbers of individuals were found in most habitats and individuals are collected frequently from the wild due to the unique shape of the flowers as well as the rarity of the species.

Plant-animal interactions often play a strong role in determining plant abundance and persistence of a plant population (Knight, 2007). A decrease of Asarum species as a keystone species in the ecosystem, is more likely to affect L. puziloi, a major pollinator of the spring ephemeral herb Erythronium japonicum, which may lead to its extinction thereby affecting E. japonicum continuously in the future.

Consequently, A. misandrum which has narrow and restricted distribution range must be conserved for maintenance of genetic variation. Especially, the habitat of population 1 (Anmyeon-do), which is one of the most famous tourists destinations in Korea and this place is not fall under any legal protection. Moreover, this habitat is placed near Anmyeon Natural Recreation Forest, which is a famous place for visitors to take a stroll in Anmyeon-do. Thus, a reasonable conservation of the populations and all biological information, which are continuous monitoring of natural habitats, seed dispersal study 
and ecological study, must be collected and this species could be designated as a rare species by IUCN categories and criteria. Also, due to low genetic differentiation among populations, the establishment of active conservation strategies to increase the number of individuals and their genetic variation including ex-situ and in-situ conservation is needed.

\section{Acknowledgement}

We are deeply grateful to Dr. Ki-Ryong Park for his kindly help. We are also indebted to an anonymous reviewer for improving our manuscript.

\section{Literature Cited}

Allendorf, F. W. and G. Luikart. 2007. Conservation and the Genetics of Population, Blackwell Publishing, USA.

Avise J. C. and J. L. Hamrick. 1996. Conservation Genetics: Case Histories from Nature. Champman \& Hall, New York.

Chung, M. G. 1994. Genetic variation and population structure in Korean endemic species: III. Hosta minor (Liliaceae). Journal of Plant Research 107: 307-383.

Gottlieb, L. D. 1981. Electrophoretic evidence and plant populations. Progress in Phytochemistry 7: 1-46.

Hamrick, J. L. and M. J. W. Godt. 1996. Conservation genetics of endemic plant species. In Conservation Genetics: Case Studies from Nature. Champman \& Hall, New York. Pp. 292.

Hamrick, J. L. and M. J. W. Godt. 1989. Allozyme diversity in plant species. In Plant Population Genetics, Breeding and Genetic Resources. Brown, A. D. H., M. T. Clegg, A. L. Kahler and B. S. Weir. (eds.), Sinauer, Sunderland. Pp. 43-63.

Huber, H. 1993. Aristolochiaceae. In The Families and Genera of Vascular Plants. Vol. 2. Kubitzki, K., J. G. Rohwer. and V. Bittrich (eds.), Springer-Verlag, Berlin. Pp. 129-137.

Ishizaki, S., T. Narumi, M. Mizushima and M. Ohara. 2010. Effect of the specialist herbivore Luehdorfia puziloi on the performance of a woodland herbaceous plant, Asarum heterotropoides. Plant Species Biology 25: 61-67.

Kang, S. S. and M. G. Chung. 1997. Genetic variation and population structure in Korean endemic species: IV. Hemerocallis hakuunensis (Liliaceae). Journal of Plant Research 110: 209217.

Kelly, L. M. 1997. A cladistic analysis of Asarum (Aristolochiaceae) and implications for the evolution of herkogamy. American Journal of Botany 84: 1752-1765.

Kelly, L. M. 1998. Phylogenetic relationships in Asarum (Aristolochiaceae) based on morphology and ITS sequences. American Journal of Botany 85: 1454-1467.
Knight, T. M. 2007. Population-level consequences of herbivory timing in Trillium grandiflorum. The American Midland Naturalist 157: 27-38.

Lu, K. L. 1982. Pollination biology of Asarum caudatum (Aristolochiaceae) in Northern California. Systematic Botany 7: 150-157.

Nei, M. 1978. Estimation of average heterozygosity and genetic distance from a small number of individuals. Genetics 89 : 583-590.

Nybom, H. and I. V. Bartish. 2000. Effects of life history traits and sampling strategies on genetic diversity estimates obtained with RAPD markers in plants. Perspectives in Plant Ecology, Evolution and Systematics 3: 93-114.

Oh, B. U., O. H. Nam and J. G. Kim. 1997. A new species of Asarum sect. Asiasarum from Korea: A. misandrum B. Oh et J. Kim. Korean Journal of Plant Taxonomy 27: 491-499. (in Korean)

Peattie, D. C. 1940. How Is Asarum Pollinated?. Castanea 5: 2429.

Reed, D. H. and R. Frankham. 2003. Correlation between fitness and genetic diversity. Conservation Biology 17: 230-237.

Shin, Y. H, 1991. Coloured Butterflies of Korea. Academy press, Seoul. Pp. 209. (in Korean)

So, S. and M. Kim. 2006. A taxonomic study of Asarum (Aristolochiaceae) in Korea. Korean Journal of Plant Taxonomy 38 : 121-149. (in Korean)

So, S., Y. Hwang, C. H. Lee and M. Kim. 2010. A new species of Asarum: A. yeonbyeonense M. Kim \& S. So. Korean Journal of Plant Taxonomy 40: 255-261. (in Korean)

So, S., B. Lee and K. R, Park. 2012. Genetic variation in populations of the Korean endemic Eranthis byunsanensis (Ranunculaceae). Korean Journal of Plant Taxonomy 42: 253-259.

Soltis, D. E., C. H. Haufler, D. C. Darrow and G. J. Gastony. 1983. Starch gel electrophoresis of ferns: a compilation of grind buffers, gel and electrode buffers, and staining schedules. American Fern Journal 73: 9-27.

Swofford, D. L. and R. B. Selander. 1981. BIOSYS-1: a FORTRAN program for the comprehensive analysis of electrophoretic data in population genetics and systematics. Journal of Heredity 72: 281-283.

Wallace, L. E. 2002. Examining the effects of fragmentation on genetic variation in Platanthera leucophaea (Orchidaceae): inferences from allozyme and random amplified polymorphic DNA markers. Plant Species Biology 17: 37-49.

Wright, S. 1965. The interpretation of population structure by Fstatistics with special regard to systems of mating. Evolution 19: 395-420.

Yamaji, H., T. Fukuda, J. Yokoyama, J. H. Pak, C. Zhou, C. Yang, 
K. Kondo, T. Morota, S. Takeda, H. Sasaki and M. Maki. 2007. Reticulate evolution and phylogeography in Asarum sect. Asiasarum (Aristolochiaceae) documented in internal transcribed spacer sequences (ITS) of nuclear ribosomal DNA. Molecular Phylogenetics and Evolution 44: 863-884.

Yamaki, K., S. Terabayashi, M. Okada, and J. H. Pak. 1996. A new species and a new variety of Asarum (Aristolochiaceae) from Korea. Journal of Japanese Botany 71: 1-10.
Yook, C. S. and J. G. Kim. 1996. A new species and two new forma of Asiasarum. Korean Journal of Pharmacognosy 27: 342-346. (in Korean)

Zhou, T. H., Z. Q. Qian, S. Li, Z. G. Guo, Z. H. Huang, Z. L. Liu and G. F. Zhao 2010. Genetic diversity of the endangered Chinese endemic herb Saruma henryi Oliv. (Aristolochiaceae) and its implications for conservation. Population Ecology 52: 223231. 